\title{
Summary of the effects of three tillage and three traffic systems on cereal yields over a four-year rotation
}

by Godwin, R.J., Misiewicz, P.A., Millington, W.A.J., White, D.R., Dickin and Chaney, K.

Copyright, publisher and additional information:

Authors' accepted version 


\title{
Summary of the effects of three tillage and three traffic systemson cereal yields over a four-year rotation
}

\author{
By R J Godwin ${ }^{1}$, P A Misiewicz ${ }^{1}$, E K Smith², W A J Millington ${ }^{1}$, D R White ${ }^{1}$, E T Dicking ${ }^{1}$ and K \\ Chaney $^{1}$ \\ ${ }^{1}$ Harper Adams University, Newport, Shropshire TF108NB, UK \\ ${ }^{2}$ AHDB Cereals and Oilseeds, Stoneleigh Park, Kenilworth, Warwickshire CV8 2TL, UK \\ Corresponding Author Email: r.godwin@iagre.biz
}

\begin{abstract}
Summary
This paper reports the design and results of a study to consider the effects of deep, shallow and zero tillage with random conventional and low tyre inflation pressures and controlled traffic systems on the yield of winter wheat, winter barley $(\times 2)$ and spring oats. The results show that crop yields for zero tillage were significantly less $(P<0.001)$ than deep and shallow tillage for all crops with an overall reduction of $1.0 \mathrm{t} \mathrm{ha}^{-1}$ below the mean of the deep and shallow tillage practices. Controlled traffic farming with a $30 \%$ trafficked area produced significantly higher yields than random conventional pressure traffic for the winter wheat and spring oats. Controlled traffic farming, with trafficked areas of $30 \%$ and $15 \%$ showed overall benefits over random conventional inflation pressure traffic of

$0.32 \mathrm{t} \mathrm{ha}^{-1}\left(\mathrm{f} 41 \mathrm{ha}^{-1}\right)$ and $0.61 \mathrm{t} \mathrm{ha}^{-1}\left(\mathrm{f} 77 \mathrm{ha}^{-1}\right)$ respectively, requiring breakeven areas of 312 ha and 168 ha to cover the costs of three vehicle guidance/auto-steering systems.
\end{abstract}

Key words: Tillage, random and controlled traffic, cereal yield

\section{Introduction}

Work in Scotland (Soane, 1970) showed that approximately $90 \%$ of a field growing spring barley was covered by wheel marks during the crop establishment operations. Using global positioning system-tracking devices Kroulik et al. (2009) revealed that random traffic farming (RTF) practices, with conventional tyre inflation pressures, for wheat production covered some $86 \%, 65 \%$ and $45 \%$ of the field with at least 1 wheel pass for conventional (plough based) tillage, minimum tillage and direct drilling/zero-till respectively. This then suggests that much could be gained from controlled traffic farming (CTF) practices where field operations are focused on predetermined wheel-ways, and equipment widths and wheel track spacing are matched. This is now made easier with the use of real time kinetic (RTK) global positioning satellite guidance and auto-steer systems.

The potential advantages through avoiding compaction from this practice are:

1. Improved crop yields, which will be the main focus of this paper.

2. Reduced tillage and crop establishment draught forces/energy.

3. Improved soil conditions and infiltration of rainfall/irrigation water. 
These are achievable providing that the mechanisation systems permit matching of the equipment operating width and wheel centre spacing. An alternative to CTF is the use of lower tyre inflation (ground) pressure systems (LGP), which has become more practical for higher power tractors with the introduction of Ultra-Flex tyres (Michelin). These tyres can operate at inflation pressures down to 0.4 bar for very low loads. However, where a tractor equipped with conventional tyres inflated to 1.2 bar and 1.5 bar for the front and rear tyres respectively the recommended inflation rate for ultra-flex tyres is typically 0.6 to 0.7 bar.

Chamen (2011) reported yield improvements between $7 \%$ and $35 \%$ for CTF systems for a range of crops in a number of different international studies. This data is very promising, however, not all of the results were from replicated experiments and soil compaction, if present, was not reported as being alleviated by soil loosening prior to the initiation of the work. In order to overcome these issues randomized, replicated studies were initiated by Cranfield University and The Arable Group (TAG) in 2007 and 2009; the Slovak University of Agriculture in 2010; and Harper Adams University, Newport, Shropshire, UK in 2011 (Godwin et al., 2015). The studies conducted by Cranfield University/TAG at Morley demonstrated winter wheat yield improvements from CTF for two tillage depths (shallow 50-150 mm and deep 150$250 \mathrm{~mm}$ ) of $15.5 \%$ and $16.4 \%$ respectively and a $12 \%$ and $5.5 \%$ improvement where the machinery operations were confined to a rubber-tracked vehicle.

Galambosova et al. (2017) reported that in Slovakia where a 16 ha field was managed using $6.0 \mathrm{~m}$ wide CTF systems with three $33 \mathrm{~m}$ wide compacted (RTF) zones crossing the direction of the CTF traffic, that CTF showed advantages over the RTF for three crops/seasons. Spring barley showed the greatest difference $(50 \%, P=0.05))$, followed by maize $(32.5 \%, P=0.15)$ and winter wheat $(10 \%, P=0.1)$.

With the exception of the work at Morley, the remainder of the work reported above was undertaken with one depth of tillage system without particular attention to the underlying soil conditions. In order to determine the effects of tillage depth (250 mm, $100 \mathrm{~mm}$ and zero-till) and traffic systems, a long-term experiment (c.10 years) was established by Harper Adams University in 2011. The effect of LGP using Ultra-Flex tyres were studied in addition to the RTF and CTF traffic systems.

\section{Materials and Methods}

A very slightly stony sandy loam (Claverley series) field was chosen for this study, which was drained at $13 \mathrm{~m}$ spacing and subsoiled to a depth of $0.5 \mathrm{~m}$ to remove deep compaction. The site had a topsoil pH 6.6 and subsoil pH 6.1. In order to locate an area of the field with the minimum heterogeneity for the experiment, both conventional soil mapping and electromagnetic resonance techniques were used. Following this, a winter wheat crop was established in forty $80 \mathrm{~m}$ long by

$4.0 \mathrm{~m}$ wide plots with $0.6 \mathrm{~m}$ wide wheel tracks at a wheel centre spacing of $2.1 \mathrm{~m}$. Plot widths of $4.0 \mathrm{~m}$ were chosen to keep the experiment within the uniform soil zone and match the readily available complement of field machines; this resulted in a trafficked area for the CTF plots of $30 \%$ of the total area. This figure should be relatively easy for farmers to achieve.

Variable traffic and tillage treatments were not applied in the first season, the site was allowed to "recover" from the pre-treatments and the spatial uniformity of the proposed plot-treatment zones determined following ploughing with a $4 \mathrm{~m}$ wide mould-board plough and power harrow/drill combination with the wheel tracks set at those for the CTF operations in 
subsequent years (Smith et al., 2013; Smith, 2016).

The plots yields were harvested using a combine harvester with a $4.0 \mathrm{~m}$ wide cutter-bar equipped with a yield monitoring device and the total yield/plot weighed. The coefficient of variation of the wheat yield of the proposed experimental site was $6.0 \%$. Following these results 36 contiguous treatment plots were chosen in four randomised complete blocks from the 40 plots to determine the relative effects of three traffic management systems, namely:

1. Random traffic farming (RTF) with conventional (1.2 and 1.5 bar) inflation pressure in the front and rear tractor tyres respectively.

2. Lower ground pressure farming (LGP) with lower ( 0.7 bar) inflation pressure in both thefront and rear tractor tyres.

3. Controlled traffic farming systems (CTF).

These traffic effects were combined with 3 tillage treatments in a $3 \times 3$ factorial design, namely: (1) Deep tillage $(250 \mathrm{~mm}),(2)$ Shallow tillage $(100 \mathrm{~mm})$ and (3) Zero tillage.

The traffic treatments were installed in the autumn of 2012, 2013, 2014 and 2015 following the traffic intensity patterns (both area and number of passes) of the tillage system reported by Kroulik et al. (2009). Both the deep and shallow tillage was conducted using $4.0 \mathrm{~m}$ wide combination (conical disc/rigid tine/press) tillage tool (Vaderstad Topdown) to cut surface residues, mix, loosen, level and reconsolidate the soil, to provide a suitable tilth for the establishment of the cereal crop following seed placement. In 2012 a "single disc" drill (Vaderstad Rapid) was used for seed placement in all treatments; an "offset V disc" drill (Vaderstad Spirit) replaced this in 2013-2016, as this was more suitable for the soil conditions. The rotation consisted of winter wheat (Duxford) (2012-2013), winter barley (Cassia) (20132014 and (2014-2015), a winter cover crop (Terralife N-Fix) (2015-2016) followed by spring oats (Aspen) (2016).

Hand harvested grain yield subsamples, for a length of $0.3 \mathrm{~m}$ were collected from the trafficked and non-trafficked areas of the CTF plots (Table 1) prior to recording the crop yields of the whole plots using the $4.0 \mathrm{~m}$ wide combine harvester (Table 2). The hand-harvested data was particularly important in assessing the effects of the traffic zones, especially with the CTF treatments as this enabled the combine harvester yields to be estimated for a CTF system with a traffic lane area of c.15\% (typically $12 \mathrm{~m}$ wide controlled traffic systems with $1.8 \mathrm{~m}$ wheel/track trafficked widths) which could further improve crop yields and is the aim of many CTF farmers. These estimates are given in the right hand column of Table 2 . The draught force and fuel consumption of the subsequent tillage and drilling operations were recorded at 8.0 $\mathrm{km} \mathrm{h}^{-1}$, using a tension dynamometer and positive displacement fuel meter.

\section{Results}

The yield data for the main effects of the hand harvested grain in Table 1 show that the yield in the traffic lane of the CTF treatments is significantly less $(P=0.03,0.01,0.004$ and 0.001 respectively) for all years/crops than that of the non-trafficked zone and that tillage has no effect on the mean yield. The effect of traffic reduces the mean yield by 2.90, 1.78, 2.03 and $1.44 \mathrm{t} \mathrm{ha}^{-1}$ for each of the 2013 to 2016 harvest dates; these are equivalent to a $31 \%, 22 \%, 17 \%$ and $18 \%$ respectively. Closer observation shows that there was a $6.08 \mathrm{t} \mathrm{ha}^{-1}$ difference in the winter wheat yield in 2013 of the zero tillage treatments where the traffic lane effects resulted in a yield of $4.34 \mathrm{t} \mathrm{ha}^{-1}$ whilst the non-trafficked zone was higher than all other treatments at $10.72 \mathrm{t} \mathrm{ha}^{-1}$. The magnitude of this differential was not repeated in subsequent years and could be due to the choice of the available drill and/or the very wet soil conditions at crop establishment in 2012. There was, however, a $2.32 \mathrm{t} \mathrm{ha}^{-1}(28 \%)$ reduction in the yield of spring 
oats in the zero tillage treatments in 2016 from the effect of wheel traffic.

The yield data for the main effects of the combine harvested grain given in Table 2 show:

1. The mean yields from the zero tillage treatment were significantly less $(P<0.001)$ than those from the deep and shallow tillage for the winter wheat (2013), winter barley (2015) and spring oats (2016). There was no significant yield difference $(P=0.857)$ between the different tillage systems for the winter barley yield in 2014. Although not significantly different, the yields from the shallow tillage treatments were marginally higher than those from the deep tillage treatments in each year of the study, agreeing with the 14 year average of wheat yields reported by Dawkins (2014) from data from commercial farms.

2. The mean yield from controlled traffic treatments $\left(\mathrm{CTF}_{30 \%}\right.$ for the $30 \%$ trafficked area) were significantly higher than the yield from the random traffic treatments for both the winter wheat (2013 (0.5 t ha-1) $P=0.073$ ) and spring oats (2016 $\left.\left(0.55 \mathrm{t} \mathrm{ha}^{-1}\right) P=0.057\right)$, with the yield of the low ground pressure system positioned approximately mid-way between them but not significantly different from either. There were no significant differences in the effects of traffic for the winter barley yield in both $2014(P=0.682)$ and $2015(P=0.84)$.

3. The probability level of 0.073 for the effects of traffic was considered acceptable for practical agriculture, because when this data was combined with that of similar studies using the method developed by Fisher to combine probabilities (Sokal \& Rohlf, 1981) with $P$ values ranging from 0.05 to 0.1 the resulting combined probability lay between 0.01 and 0.001 (Godwin et al., 2015).

4. There was no significant interaction between the effects of tillage and traffic for any crop/ season.

Table 1. Hand harvested yields ( $t \mathrm{ha}^{-1}$ ) in the traffic lanes and non-trafficked zones of the controlled traffic system plots. Means not followed by the same letter are significantly different at 5\% probability. (Smith et al., 2013; Smith, 2016; Millington et al., 2016; W A J Millington, 2016 pers. comm)

\begin{tabular}{|c|c|c|c|}
\hline & Traffic lane & Non-trafficked & Mean \\
\hline Winter Wheat 2013 & & Traffic $\mathrm{LSD}_{5 \%}=1.78$ & \\
\hline Deep Tillage & 7.69 & 8.97 & $8.33 a$ \\
\hline Shallow Tillage & 7.04 & 8.10 & $7.57 a$ \\
\hline Zero Tillage & 4.34 & 10.72 & $7.53 a$ \\
\hline Mean & $6.36 a$ & $9.26 b$ & \\
\hline Winter Barley 2014 & & Traffic LSD $_{5 \%}=1.27$ & \\
\hline Deep Tillage & 6.06 & 8.69 & $7.37 a$ \\
\hline Shallow Tillage & 6.22 & 7.68 & $6.95 a$ \\
\hline Zero Tillage & 6.79 & 8.06 & $7.42 a$ \\
\hline Mean & $6.36 a$ & $8.14 b$ & \\
\hline Winter Barley 2015 & & Traffic $L S D_{5 \%}=1.26$ & \\
\hline Deep Tillage & 9.87 & 13.24 & $11.55 a$ \\
\hline Shallow Tillage & 10.69 & 12.53 & $11.61 a$ \\
\hline Zero Tillage & 10.00 & 10.90 & $10.45 a$ \\
\hline Mean & 10.19a & $12.22 b$ & \\
\hline Spring Oats 2016 & & Traffic $\mathrm{LSD}_{5 \%}=0.75$ & \\
\hline Deep Tillage & 7.33 & 8.33 & $7.83 a$ \\
\hline
\end{tabular}


Table 2 also shows the estimated crop yield for a $\mathrm{CTF}_{15 \%}$ system. This data was estimated by re- proportioning the whole plot $\mathrm{CTF}_{30 \%}$ yield in Table 2 using the relative yields of the trafficked and non-trafficked zones from the data in Table 1 for each of the tillage systems. The mean yield for the three tillage systems for each crop/year shows a $4.8 \%, 3.5 \%, 2.4 \%$ and $2.7 \%$ yield improvement over $\mathrm{CTF}_{30 \%}$ with a mean improvement of $3.4 \%$.

Table 2. Combine harvested yields (t ha $a^{-1}$ ) for a range of tillage and traffic systems.

Means not followed by the same letter are significantly different at the quoted probability

level. The right hand column shows the estimated yields for controlled traffic systems with a traffic lane area of 15\%. (Smith et al., 2013; Smith, 2016; W A J Millington, 2016 pers. comm)

\begin{tabular}{|l|l|c|l|}
\hline RandomTraffic & Low & Controlled & Mean \\
RTF & Ground & Traffic & \\
& Pressure & CTF $_{30 \%}$ & \\
& LGP & & \\
\hline
\end{tabular}

\begin{tabular}{|c|c|c|c|c|c|}
\hline \multirow{2}{*}{$\begin{array}{l}\text { Winter Wheat } 2013 \\
\text { Deep Tillage }\end{array}$} & \multicolumn{5}{|c|}{ Traffic and Tillage $\operatorname{LSD}_{10 \%=} 0.35$} \\
\hline & 7.29 & 7.71 & 7.93 & $7.65 b$ & 8.11 \\
\hline Shallow Tillage & 7.67 & 7.93 & 8.39 & $8.00 b$ & 8.56 \\
\hline Zero Tillage & 6.87 & 7.02 & 7.01 & $6.97 a$ & 7.78 \\
\hline Mean & $7.28 a$ & $7.55 a b$ & $7.78 b$ & 7.54 & 8.15 \\
\hline Winter Barley 2014 & \multicolumn{5}{|c|}{ No significant difference } \\
\hline Deep tillage & 8.50 & 8.50 & 8.50 & $8.50 a$ & 8.92 \\
\hline Shallow Tillage & 8.60 & 8.20 & 9.10 & $8.63 a$ & 9.37 \\
\hline Zero Tillage & 8.80 & 8.60 & 8.40 & $8.60 \mathrm{a}$ & 8.61 \\
\hline Mean & $8.63 a$ & $8.43 a$ & $8.67 a$ & 8.58 & 8.97 \\
\hline Winter Barley 2015 & \multicolumn{5}{|c|}{ 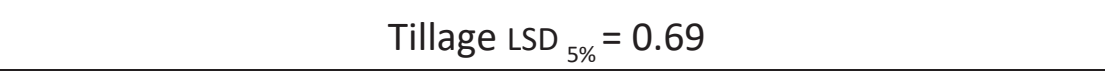 } \\
\hline Deep Tillage & 11.17 & 11.46 & 11.53 & $11.39 \mathrm{~b}$ & 11.93 \\
\hline Shallow Tillage & 11.53 & 11.61 & 11.40 & $11.51 b$ & 11.67 \\
\hline Zero Tillage & 9.93 & 9.99 & 10.28 & $10.07 a$ & 10.41 \\
\hline Mean & $10.88 a$ & $11.02 a$ & $11.07 a$ & 10.99 & 11.34 \\
\hline Spring Oats 2016 & \multicolumn{5}{|c|}{ 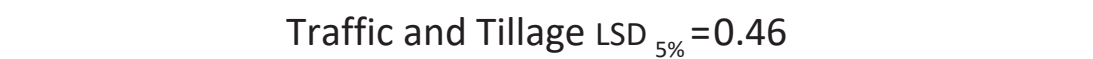 } \\
\hline Deep Tillage & 8.61 & 8.96 & 9.12 & $8.89 \mathrm{~b}$ & 9.28 \\
\hline Shallow Tillage & 8.81 & 8.86 & 9.06 & $8.91 b$ & 9.23 \\
\hline Zero Tillage & 6.70 & 6.91 & 7.60 & $7.07 a$ & 7.95 \\
\hline Mean & $8.04 a$ & $8.24 a b$ & $8.59 b$ & 8.29 & 8.82 \\
\hline
\end{tabular}

Yield comparison between the CTF $15 \%$ and the RTF for the deep and shallow tillage systems (not including zero-tillage as this had a significantly lower yield than the other tillage systems in 3 of the 4 years) shows that $\mathrm{CTF}_{15 \%}$ produced annual yield improvements of $0.86 \mathrm{t}$ ha $\mathrm{s}_{-1}(11.4 \%), 0.6 \mathrm{t}$ $\mathrm{ha}^{-1}(7 \%), 0.45 \mathrm{t} \mathrm{ha}^{-1}(4.0 \%)$ and $0.55 \mathrm{t} \mathrm{ha}^{-1}(6.3 \%)$ respectively.

The mean annual yield and the mean annual value of the crops for the 4 years data is given in 
Fig. 1 for the tillage systems (upper) and traffic systems (lower). The mean annual value is based upon the November 2016 grain prices from AHDB Cereals and Oilseeds of wheat at $£ 140$ $t^{-1}$, barley $f 110 t^{-1}$ and oats $£ 125 t^{-1}$. The tillage data show that the differences between the zero tillage treatments and that of the mean of the shallow and deep tillage systems are at $1.0 \mathrm{t} \mathrm{ha}^{-1}$ and $f 124 \mathrm{ha}^{-1}$. Similarly, LGP systems show a small overall benefit of $0.1 \mathrm{t} \mathrm{ha}^{-1}$ and $\mathrm{f15} \mathrm{ha}^{-1}$ over the RTF

system. The CTF 
and $\mathrm{CTF}_{15 \%}$ 
show yield benefits of $0.32 \mathrm{t} \mathrm{ha}^{-1}$ and $0.61 \mathrm{tha}^{-1}$ and economic benefits of $£ 41$ ha $^{-1}$ and $£ 77$ ha $^{-1}$ respectively.

Assuming that a farmer or contractor contemplating CTF would initially use existing equipment and that improvements to equipment matching would be part of the normal longer-term replacement policy the main additional cost would, therefore, be the investment in vehicle guidance/auto- steering systems. Following the procedures undertaken by the authors, reported in Hargreaves et al. (2017), the annual cost of a single high accuracy, RTK (+/- $20 \mathrm{~mm}$ ) fully integrated vehicle guidance system; based upon a capital cost of $£ 15,000$ and an annual RTK subscription fee of $£ 500$

year ${ }^{-1}$ with: interest rates of $4.5 \%$, depreciation of $15 \%$, maintenance of $5 \%$ and training of $£ 100$ year $^{-1}$ (Nix, 2015) is $£ 4275$. The cost per ha is given in Fig. 2 This shows that the cost declines for a range of harvest areas from $£ 85$ ha $^{-1}$ for 50 ha to $£ 4.3$ ha $^{-1}$ for 1000 ha. Comparing the $£ 41 \mathrm{ha}^{-1}$ and $£ 77 \mathrm{ha}^{-1}$ CTF benefits over RTF with the curve in Fig. 2. gives breakeven areas of 104 ha and 56 ha for the implementation of CTF systems. In practice a number of guidance systems would be required to support the tractors, combine harvester and other associated field equipment required for CTF. Hence if three systems were required the breakeven areas would increase to 312 ha and 168 ha for $\mathrm{CTF}_{30 \%}$ and $\mathrm{CTF}_{15 \%}$ respectively.
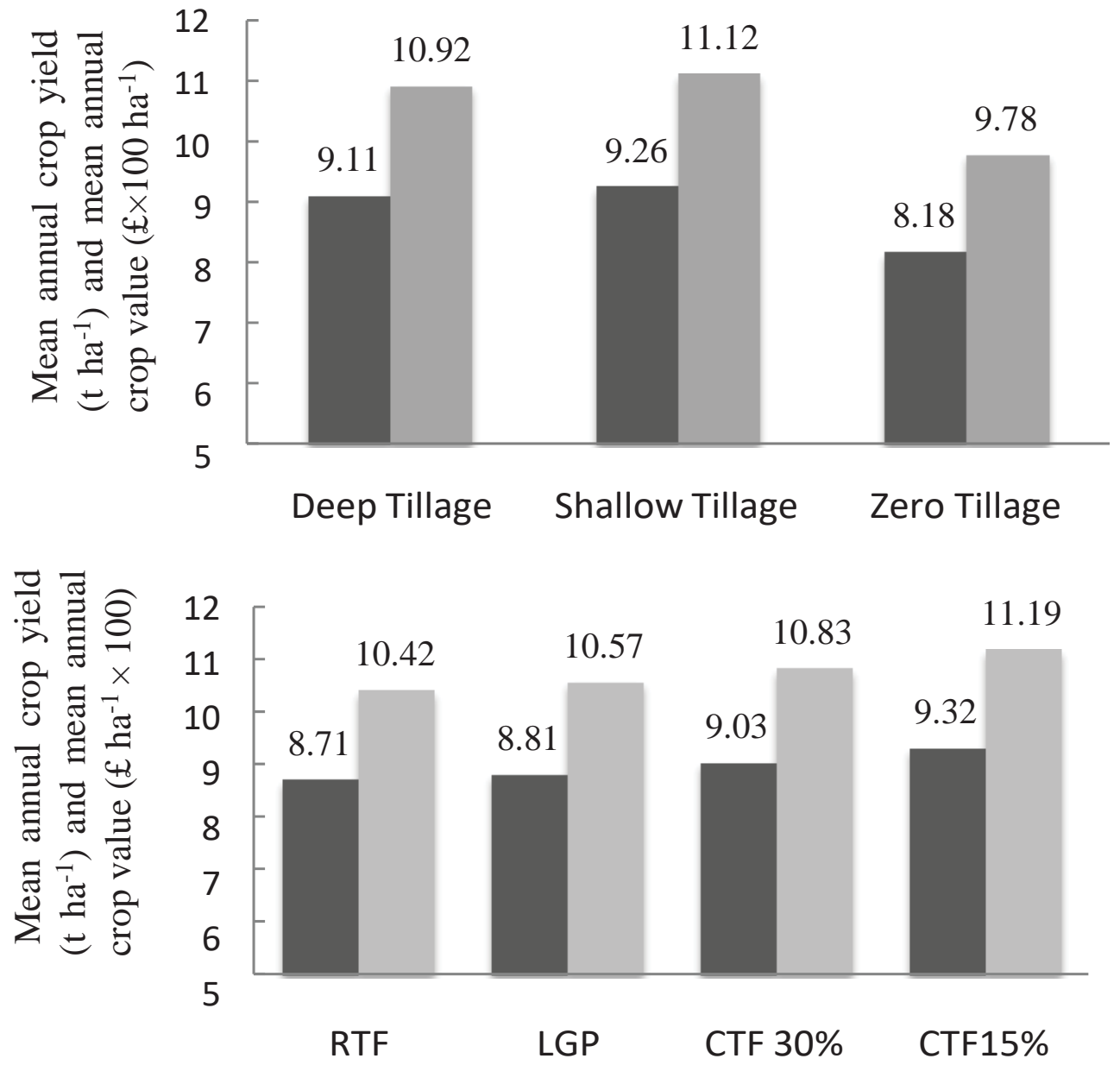

\section{Mean annual crop yield $\quad$ Mean annual crop value}

Fig. 1. Overall effect of tillage (upper) and traffic (lower) systems on mean annual yields and mean annual crop value for the four experimental seasons.

Assuming that a farmer or contractor contemplating CTF would initially use existing equipment and that improvements to equipment matching would be part of the normal longer-term replacement policy the main additional cost would, therefore, be the investment in vehicle 
guidance/auto- steering systems. Following the procedures undertaken by the authors, reported in Hargreaves et al. (2017), the annual cost of a single high accuracy, RTK ( $\pm 20 \mathrm{~mm}$ ) fully integrated vehicle guidance system; based upon a capital cost of $£ 15,000$ and an annual RTK subscription fee of $£ 500$ year ${ }^{-1}$ with: interest rates of $4.5 \%$, depreciation of $15 \%$, maintenance of $5 \%$ and training of $£ 100$ year $^{-1}(\mathrm{Nix}, 2015)$ is $f 4275$. The cost per ha is given in Fig. 2 . This shows that the cost declines for a range of harvest areas from $£ 85 \mathrm{ha}^{-1}$ for 50 ha to $£ 4.3 \mathrm{ha}^{-1}$ for 1000 ha. Comparing the $£ 41 \mathrm{ha}^{-1}$ and $f 77 \mathrm{ha}^{-1}$ CTF benefits over RTF with the curve in Fig. 2. gives breakeven areas of 104 ha and 56 ha for the implementation of CTF systems. In practice a number of guidance systems would be required to support the tractors, combine harvester and other associated field equipment required for CTF. Hence if three systems were required the breakeven areas would increase to 312 ha and 168 ha for $\mathrm{CTF}_{30 \%}$ and $\mathrm{CTF}_{15 \%}$ respectively. 


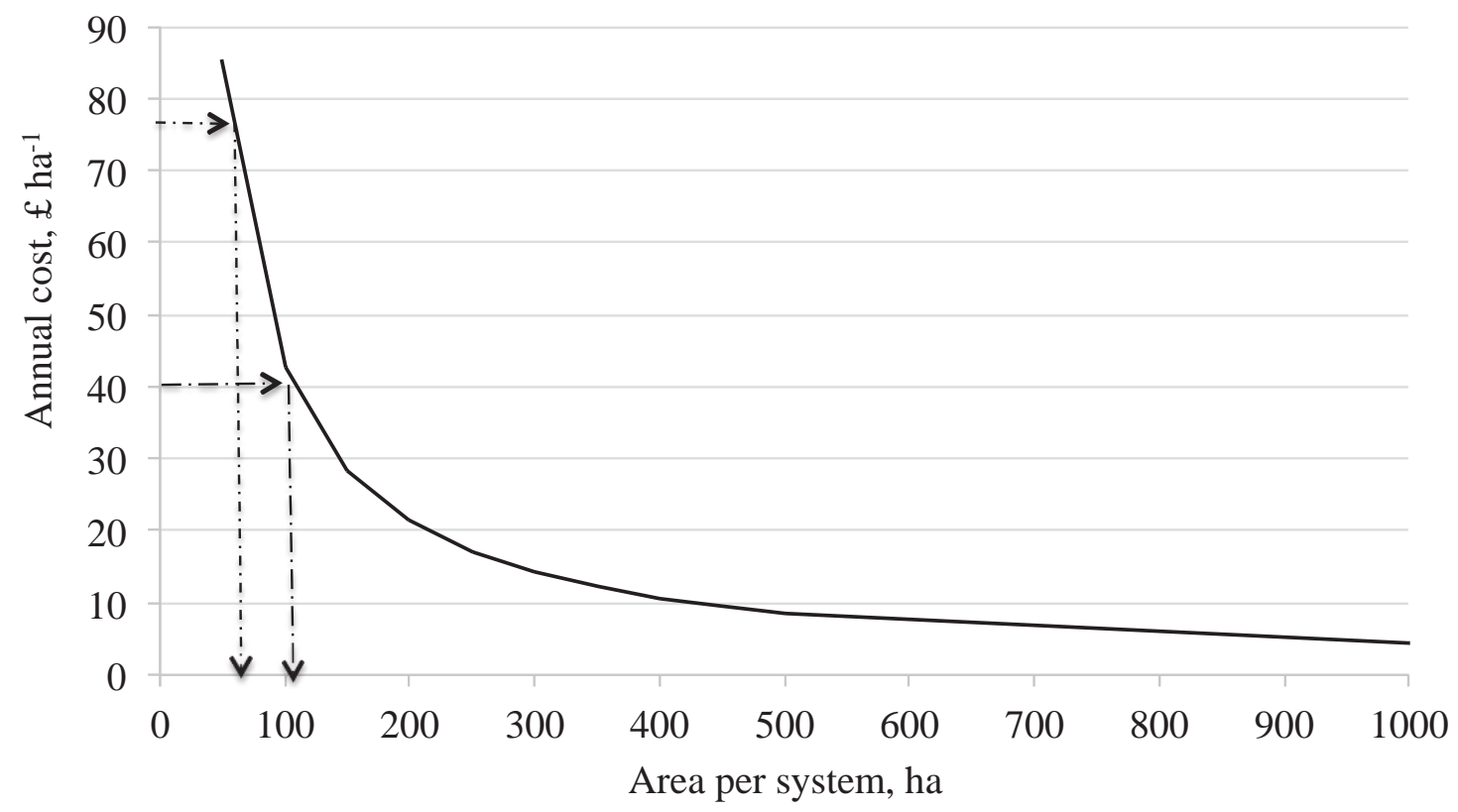

Fig. 2. Break even comparisons of the mean annual economic benefits of $\mathrm{CTF}_{30 \%}$ (long dash - dot line) and $\mathrm{CTF}_{15 \%}$ (short dash - dot line) over RTK with the annual cost of operation of a high accuracy (RTK), fully integrated steering vehicle guidance system (solid line).

The draught forces and fuel consumption of the tillage and drilling operations at a speed of $8.0 \mathrm{~km} \mathrm{~h}^{-1}$ in 2013 were recorded (Arslan et al., 2014) and are presented in Table 3. The data showed significant $(P<0.05)$ differences in the tillage operations but no difference in draught force of the drill and the traffic systems (not shown). Also given are the fuel costs at $f 0.50 \mathrm{I}^{-1}$.

Table 3. Mean draught forces, fuel consumption and fuel costs at $10.50 \mathrm{l}^{-1}$ for the 3 tillage systems. Means not followed by the same letter are significantly different $(P<0.05)$, Arslan et al., 2014

\begin{tabular}{ccccc}
\hline Treatment & $\begin{array}{c}\text { Tillage draught } \\
\text { force, } \mathrm{kN}\end{array}$ & $\begin{array}{c}\text { Drill draught } \\
\text { force, } \mathrm{kN}\end{array}$ & $\begin{array}{c}\text { Fuel } \\
\text { tilkogesandpdirih, } \mathrm{L} \mathrm{ha}^{-1}\end{array}$ & $\begin{array}{c}\text { Fuel cost } \\
£ \mathrm{ha}^{-1}\end{array}$ \\
\hline Deep tillage, $250 \mathrm{~mm}$ & $64.9 \mathrm{a}$ & $15.9 \mathrm{a}$ & $22.16 \mathrm{a}$ & $11.08 \mathrm{a}$ \\
Shallow tillage, $100 \mathrm{~mm}$ & $21.3 \mathrm{~b}$ & $16.7 \mathrm{a}$ & $16.42 \mathrm{~b}$ & $8.21 \mathrm{~b}$ \\
Zero-till & $00.0 \mathrm{c}$ & $16.5 \mathrm{a}$ & $8.82 \mathrm{c}$ & $4.41 \mathrm{c}$ \\
\hline
\end{tabular}

\section{Discussion}

The reduced yields from the zero-tillage treatments was disappointing as many farmers are looking to this technique to reduce the time and costs of tillage operations (Godwin, 2014). However, it was not unexpected as the data given by Cannell (1978) and Soane et al. (2012) would suggest that the climatic conditions are not ideal for zero tillage in the wetter western parts of the UK. Improvements to the soil conditions in the wheel-ways, by a shallow wheel mark eradication operation, especially in the 2012-13 season could have been of benefit. The longer term expected recovery for crop yields grown using zero tillage as suggested by Carter 
(1994) did not materialize, although zero tillage gave comparable yields to the other tillage systems in the winter barley in 2013-14. 
Overall the CTF system performed well, giving yield improvements at levels for most practical farmers to consider the adoption of the practice. The estimated yield improvement for CTF systems with a trafficked area of $15 \%$ demonstrates the benefit the lower trafficked area systems. The results are not as high as some of those reported in earlier studies by Chamen (2011) and Galambosova et al. (2016) but are economically viable.

Breakeven areas of 312 ha and 168 ha may appear high to farms with smaller cropped areas; the adoption of less accurate vehicle guidance/auto-steering systems with a capital cost of c. $£ 5000$ reduces the annual costs to $£ 1325$ system (Hargreaves et al., 2016) and result in breakeven areas of 97 ha and 52 ha respectively for three systems.

Reducing the tyre inflation pressure of the random traffic system, in the two seasons where the traffic system had a significant effect, resulted in crop yields that lay approximately midway between the random traffic (with higher inflation pressures) and the controlled traffic system with a trafficked area of $30 \%$. The relative benefit of this in comparison with those of the other systems, alongside the fuel consumption data, will be of importance when undertaking a full economic evaluation.

\section{Conclusions}

1. Crop yields for the zero tillage treatments were significantly less $(P<0.001)$ than deep and shallow tillage for winter wheat, winter barley and spring oats in 2013, 2015 and 2016 respectively. Albeit the hand harvest data for the 2013 winter wheat showed a significant improvement in yield in the non-trafficked areas. Integrating all the tillage data shows that zero-till yields were $1 \mathrm{t} \mathrm{ha}^{-1}$ and $£ 124 \mathrm{ha}^{-1}$ below the mean of deep and shallow tillage.

2. The overall the effect of traffic in the CTF plots significantly $(P=0.03,0.01,0.004$ and 0.001 for each year respectively) reduced the yield in the trafficked lane by between $1.44 \mathrm{t} \mathrm{ha}^{-1}$ and

$2.90 \mathrm{t} \mathrm{ha}^{-1}$ or $17 \%$ to $31 \%$ from that of the non-trafficked zone.

3. The controlled traffic farming system with a $30 \%$ trafficked area had a significantly higher yield over RTF for the winter wheat $(P=0.073)$ and spring oats $(P=0.057)$ in 2013 and 2016 respectively but were not significantly different in the two winter barley crops. The grain yields from the low ground pressure traffic management system are approximately mid-way between them.

4. Reducing the trafficked area from $30 \%$ to $15 \%$ increased the 4 year mean yield by $3.4 \%$. The CTF $_{30 \%}$ and CTF $_{15 \%}$ show benefits over RTF of $0.32 \mathrm{t} \mathrm{ha}^{-1}$ and $0.61 \mathrm{tha}^{-1}$ equivalent to $£ 41 \mathrm{ha}^{-1}$ and $\mathrm{f} 77 \mathrm{ha}^{-1}$ respectively.

5. The breakeven areas to cover the additional costs of three RTK vehicle guidance systems at 2016 grain prices are 312 ha and 168 ha for $\mathrm{CTF}_{30 \%}$ and $\mathrm{CTF}_{15 \%}$ respectively.

6. The draught forces and fuel consumption of the tillage and drilling operations showed significant $(P<0.05)$ differences between the depth of the tillage operations but no significant difference in the draught force and fuel consumption for the drilling operation and the different traffic systems.

\section{Acknowledgements}

The authors would like to express their thanks to (i) the main sponsors of this work: The Douglas Bomford Trust, Manufacture Francaise Des Pneumatiques Michelin and Vaderstad UK 
Ltd; (ii) the other organisations that have loaned equipment and services: AGCO, Rea Valley Tractors, Precision Decisions and SOYL; and (iii) the staff of Harper Adams University, particularly Tim Dicker and Sean Lewis. 


\section{References}

Arslan S, Misiewicz P A, Smith E K, Tsiropoulos Z, Girardello V, White D R, Godwin R J. 2014. Fuel consumptions and draft power requirements of three soil tillage methods and three field traffic systems. Paper 1900051. St Joseph, Michigan, USA: ASABE

Cannell R Q, Davies D B, Mackney D, Pidgeon J D. 1978. The suitability of soils for sequential direct drilling of combine harvested crops in Britain: a provisional classification. Outlook on Agriculture 9(6):306-316.

Carter M R. 1994. Conservation tillage in temperate agroecosytems. Boca Raton, USA: Lewis Publishers Inc.

Chamen W C T. 2011. The effects of low and controlled traffic systems on soil physical properties, yields and the profitability of cereal crops on a range of soil types. Cranfield, Bedfordshire, UK: PhD Thesis, Cranfield University.

Dawkins T C K. 2014. A review of restraints to arable crop production: crop and soil interactions. Aspects of Applied Biology 127, Crop Production in Southern Britain: Precision Decisions for Profitable Cropping, pp. 201-209.

Galambošová J, Macák M, Rataj V, Antille D L, Godwin R J, Žitňák M, Vitázková B, Ďud'ák J, Chamen W C T, Chlpík J. 2017. Agronomic assessment of arable crops established in soils under controlled and random traffic regimes: a synthesis of three years of field-scale experimentation in Nitra, Slovakia. Transactions of the American Society of Agricultural Engineers. St Joseph, Michigan, USA. (In press).

Godwin R J. 2014. Potential of "No-till" Systems for Arable Farming. London, UK: The Worshipful Company.

Godwin R J, Misiewicz PA, White D R, Smith E K, Chamen W C T, Galambosova J, Stobart

R. 2015. Results from recent traffic systems research and implications for future work. Acta Technologica Agriculturae 3(Nitra):57-63.

Hargreaves P, Peets S, Chamen W C T, Misiewicz P A, White D R, Godwin R J. 2017. Controlled Traffic Farming: Methods applied to Grassland Silage Management. Stoneleigh Park, Kenilworth, Warwickshire, UK: AHDB Dairy Report (In press).

Kroulik M, Kumhala F, Hula J, Honzik I. 2009. The evaluation of agricultural machines field trafficking intensity for different soil tillage technologies. Soil and Tillage Research 105:171-175. Millington W A J, Misiewicz PA Dickin E T, White D R, Godwin R J. 2016. An investigation into the effect of soil compaction and tillage on plant growth and yield of winter barley (Hordeum vulgare L.). Paper 162461725. St Joseph, Michigan, USA: ASABE.

Nix J. 2015. Farm Management Pocketbook, $46^{\text {th }}$ (2016) Edition. Melton Mowbray, UK: Agro Business Consultants Ltd.

Soane B D. 1970. The effects of traffic and implements on soil compaction. Journal of the Proceedings of the Institute of Agricultural Engineers 25:115-125.

Soane B D, Ball B C, Arvidsson J, Basch G, Moreno F, Roger-Estrande J. 2012. No-till in northern, western and south-western Europe: A review of problems and opportunities for crop production and the environment. Soil and Tillage Research 118:66-87.

Sokal R R, Rohlf F J. 1981. Biometry. The principles and practices of statistics in biological research, 2nd edition. San Francisco, USA: W. H. Freeman and Company.

Smith E K, Misiewicz P A, White D R, Chaney K, Godwin R J. 2013. An investigation into the effect of traffic and tillage on soil properties and crop yields. Paper 1597846, St. Joseph, Michigan, USA: ASABE. 
Smith E K. 2016. The effect of agricultural traffic and tillage on soil physical properties and crop yields. Cranfield, Bedfordshire, UK: PhD thesis, Cranfield University. 